\title{
The effect of seasonality on oxidative metabolism in Nacella (Patinigera) magellanica ${ }^{\text {is }}$
}

\author{
Gabriela Malanga $^{\text {a }}$, María Susana Estevez ${ }^{b}$, Jorge Calvo ${ }^{\text {a }}$, Doris Abele ${ }^{c}$, Susana Puntarulo ${ }^{\text {b,* }}$ \\ ${ }^{\text {a }}$ Centro Austral de Investigaciones Cientificas (CADIC-CONICET) c.c. 92 (9410) Ushuaia, Tierra del Fuego, Argentina \\ ${ }^{\mathrm{b}}$ Physical Chemistry-PRALIB, School of Pharmacy and Biochemistry, University of Buenos Aires, Buenos Aires, Argentina \\ ${ }^{\mathrm{C}}$ Alfred Wegener Institute for Polar and Marine Research, Bremerhaven, Germany
}

Received 8 September 2005; received in revised form 20 January 2006; accepted 21 January 2006

Available online 3 March 2006

\begin{abstract}
We studied the seasonal variation on aerobic metabolism and the response of oxidative stress parameters in the digestive glands of the subpolar limpet Nacella (P.) magellanica. Sampling was carried out from July (winter) 2002 to July 2003 in Beagle Channel, Tierra del Fuego, Argentina. Whole animal respiration rates increased in early spring as the animals spawned and remained elevated throughout summer and fall (winter: $0.09 \pm$ $0.02 \mu \mathrm{mol} \mathrm{O} \mathrm{h}^{-1} \mathrm{~g}^{-1}$; summer: $0.31 \pm 0.06 \mu \mathrm{mol} \mathrm{O}_{2} \mathrm{~h}^{-1} \mathrm{~g}^{-1}$ ). Oxidative stress was assessed at the hydrophilic level as the ascorbyl radical content/ ascorbate content ratio $\left(\mathrm{A}^{\cdot} / \mathrm{AH}^{-}\right)$. The $\mathrm{A}^{\cdot} / \mathrm{AH}^{-}$ratio showed minimum values in winter $\left(3.7 \pm 0.210^{-5} \mathrm{AU}\right)$ and increased in summer $(18 \pm 5$ $\left.10^{-5} \mathrm{AU}\right)$. A similar pattern was observed for lipid radical content $\left(122 \pm 29 \mathrm{pmol} \mathrm{mg}^{-1}\right.$ fresh mass [FW] in winter and $314 \pm 45 \mathrm{pmol} \mathrm{mg}^{-1} \mathrm{FW}$ in summer), iron content $\left(0.99 \pm 0.07\right.$ and $2.7 \pm 0.6 \mathrm{nmol} \mathrm{mg}^{-1} \mathrm{FW}$ in winter and summer, respectively) and catalase activity $\left(2.9 \pm 0.2\right.$ and $7 \pm 1 \mathrm{U}^{-1}$ FW in winter and summer, respectively). Since nitrogen derived radicals are thought to be critically involved in oxidative metabolism in cells, nitric oxide content was measured and a significant difference in the content of the Fe-MGD-NO adduct in digestive glands from winter and summer animals was observed. Together, the data indicate that both oxygen and nitrogen radical generation rates in $N$. (P.) magellanica are strongly dependent on season.
\end{abstract}

(C) 2006 Elsevier Inc. All rights reserved.

Keywords: Antioxidants; Beagle Channel; Nacella (P.) magellanica; Oxidative stress; Seasonality

\section{Introduction}

Metabolic rates, locomotory activity and growth rates in marine ectotherms are a function of temperature and of the seasonality of food availability in temperate and Antarctic waters (Ahmad and Chaplin, 1979; Kirchin et al., 1992). As food resources for most animals are more abundant during spring and summer in seasonality variable environments, many benthic

\footnotetext{
is This paper is part of a special issue of CBP dedicated to "The Face of Latin American Comparative Biochemistry and Physiology" organized by Marcelo Hermes-Lima (Brazil) and co-edited by Carlos Navas (Brazil), Rene Beleboni (Brazil), Tania Zenteno-Savín (Mexico) and the editors of CBP. This issue is in honour of Cicero Lima and the late Peter W. Hochachka, teacher, friend and devoted supporter of Latin American science.

* Corresponding author. Fisicoquímica, Facultad de Farmacia y Bioquímica, Junín 956, 1113 Buenos Aires, Argentina. Tel.: +54 114964 8244; fax: +54 11 45083646.

E-mail address: susanap@ffyb.uba.ar (S. Puntarulo).
}

grazers and detritus feeders cease feeding for weeks to months in winter (Brockington and Peck, 2001). As a result, metabolic rates may decrease to a minimum level. The influence of feeding on metabolic rates has been demonstrated by Brockington and Clarke (2001) in the Antarctic sea urchin Sterechinus neumayeri, in which food deprivation resulted in a reduction of the typical summer metabolic rate increase by $80-85 \%$. In temperate animals the effect of seasonal temperature changes on metabolic rates is generally more pronounced than in Antarctic ectotherms, because of the higher seasonal temperature variability. However, the effects of feeding and somatic and gonadal growth are also important (Schöttler, 1989; Heilmayer et al., 2005). These seasonal variations in metabolic rate are assumed to entail corresponding alterations in reactive oxygen species (ROS) formation (for review see Abele and Puntarulo, 2004). Indeed, seasonal changes in free radical metabolism have frequently been reported in marine ectotherms, including cichlid fish (Wilhelm Filho et al., 2001a), estuarine polychaetes (Abele-Oeschger et al., 
1994; Geracitano et al., 2004; Keller et al., 2004) and in various bivalve species (Viarengo et al., 1991; Solé et al., 1995; Wilhelm Filho et al., 2001b). Specifically, a decrease in the activity of antioxidant defenses in the digestive gland of Mytilus edulis has been observed in winter, accompanied by an increase in the lipid peroxidation marker, TBARS (Viarengo et al., 1991). Wilhelm Filho et al. (2001b) reported an increase in oxygen consumption, endogenous antioxidants and TBARS in summer in brown mussels (Perna perna) from Southern Brazil in comparison to winter. This fact was attributed to the reproductive activity of the animals. Lesser and Kruse (2004) investigated seasonal activity changes of the intermediary metabolism of subtidal horse mussels, Modiolus modiolus (Isle of Shoals, New Hampshire). Their study revealed no seasonal increase in either SOD activity or protein levels, although respiration rates were significantly higher during summer. In the polychaete Arenicola marina, Keller et al. (2004) reported a 5-fold increase of SOD and catalase activities in summer vs. winter animals. The activity increase corresponded to the higher metabolic rates of whole animals (Schöttler, 1989) and mitochondria during the summer reproductive season. There appears to be a trend towards higher antioxidant enzyme activities during the summer months, in particular in intertidal marine invertebrates. However, currently little knowledge exists on seasonal changes in antioxidant enzyme activities in subpolar marine molluscs.

Limpets are archaeogastropod molluscs that inhabit intertidal rocky shores. Nacella (Patinigera) magellanica is one of the most conspicuous limpet species in the Beagle Channel due to its abundance and relatively large size. The subpolar $N$. (P.) magellanica inhabits the medium and superior intertidal zones (Morriconi and Calvo, 1993; Morriconi, 1999). Due to the intertidal localization of $N$. (P.) magellanica the animals are exposed to a wide variety of environmental stressors: tidal immersion/emersion cycles, sharp salinity variations, extreme temperature effects, solar and UV radiation and anthropogenic influences. $N$. (P.) magellanica gonads ripen from July to October (winter to early spring) with a partial spawning event occurring in September, while the main spawning event takes place at the end of spring (November/December) (Morricone, 2005). Since the digestive gland is directly affected by the animals feeding status and is also a major target for oxidative disruption related to environmental stress (Malanga et al., 2004; Livingstone, 1991) this study was focussed on the limpet digestive gland to investigate seasonal changes in antioxidants defenses (enzymatic activities, content of water and lipid soluble antioxidants), as well as radical formation (lipid-, ascorbylradicals and nitric oxide). Also, as limpets in Antarctica have been found to incorporate high amounts of iron primarily mainly into digestive gland tissues (Ahn et al., 2002, 2004) iron content has been measured for comparison.

\section{Materials and methods}

\subsection{Collection of animals}

Nacella (P.) magellanica (Gastropoda, Patellogastropoda, Nacellidae) sampling was carried out from July 2002 to July
2003 in the intertidal Punta Occidental $\left(54^{\circ} 50^{\prime} \mathrm{S}, 68^{\circ} 20^{\prime} \mathrm{W}\right)$, Ushuaia Peninsula in Beagle Channel (Argentina). Only adult animals with a minimum shell length of $50 \mathrm{~mm}$ were sampled. No differentiation was made with respect to either sex or reproductive stage. Immediately after collection, animals were dissected and digestive glands were frozen at $-40^{\circ} \mathrm{C}$. Animals for respiratory measurements were maintained in natural seawater at 31.2 PSU at the same water temperature as they were collected, without feeding, for $24 \mathrm{~h}$ prior to respiration measurements. Light: dark cycle in the aquarium was $12: 12 \mathrm{~h}$.

\subsection{Respiration rate}

Whole animal respiratory rate was measured at in situ temperature (see Table 1) for each seasonal group using the method of Peck and Veal (2001). Respiration was measured using a Rank Brothers oxymeter (Cambridge, Great Britain) equipped with a closed chamber of $370 \mathrm{~mL}$ volume. Prior to respiration measurements the shells were cleaned with alcohol to remove epibenthos. Preliminary trials demonstrated that respiration rates were independent of water oxygen content down to oxygen levels that were $75 \%$ of control chambers containing no limpets. Animals were left undisturbed for $24 \mathrm{~h}$ within the respirometer, after which oxygen consumption was recorded over $6 \mathrm{~h}$. Respirometer $\mathrm{PO}_{2}$ was maintained between $75 \%$ and $100 \%$ saturation over the measurement period.

\subsection{Ascorbyl radical content $\left(A^{\circ}\right)$}

A Bruker ECS 106 spectrometer was used for $\mathrm{A}^{\circ}$ measurements. Homogenates from digestive glands were prepared in pure dimethylsulfoxide (DMSO) $(1: 3)$ and the spectra were scanned at room temperature under the following conditions: $50 \mathrm{kHz}$ field modulation, microwave power $20 \mathrm{~mW}$, modulation amplitude $1 \mathrm{G}$, time constant $655 \mathrm{~ms}$, receiver gain $110^{5}$, microwave frequency $9.81 \mathrm{GHz}$, and scan rate $0.18 \mathrm{G} / \mathrm{s}$ (Giulivi and Cadenas, 1993). Quantification was performed according to Kotake et al. (1996). The amount of spin adduct was calibrated using an aqueous solution of TEMPO, introduced

Table 1

Shell length, body wet weight and tissue specific oxygen uptake in digestive glands from Nacella $(P$.) magellanica

\begin{tabular}{|c|c|c|c|c|c|}
\hline Season & $\begin{array}{l}T_{\text {water }} \\
\left({ }^{\circ} \mathrm{C}\right)\end{array}$ & $\begin{array}{l}\text { Shell } \\
\text { length } \\
(\mathrm{mm})\end{array}$ & $I_{\mathrm{w} / 1}$ & $\begin{array}{l}\text { Animal } \\
\text { fresh } \\
\text { mass }(g)\end{array}$ & $\begin{array}{l}\mathrm{MO}_{2} \\
(\mu \mathrm{mol} \\
\mathrm{O}_{2} \mathrm{~g}^{-1} \\
\left.\mathrm{FW} \mathrm{h}^{-1}\right)\end{array}$ \\
\hline Winter (July 2002) & 3 & $51 \pm 2$ & $0.32 \pm 0.13$ & $16 \pm 1$ & $0.09 \pm 0.02$ \\
\hline Spring (October 2002) & 8 & $53 \pm 1$ & $0.27 \pm 0.08$ & $14 \pm 2$ & $0.23 \pm 0.02$ \\
\hline Summer (January 2003) & 10 & $54 \pm 3$ & $0.25 \pm 0.04$ & $12 \pm 2$ & $0.31 \pm 0.06$ \\
\hline Fall (April 2003) & 7 & $56 \pm 3$ & $0.33 \pm 0.08$ & $17 \pm 4$ & $0.24 \pm 0.03$ \\
\hline Winter (July 2003) & 3 & $56 \pm 4$ & $0.31 \pm 0.08$ & $18 \pm 4$ & $0.07 \pm 0.02$ \\
\hline
\end{tabular}


into the same cell used for spin trapping. EPR spectra of spin adduct solution and TEMPO solution were recorded at exactly the same spectrometer settings and the first-derivative EPR spectra were double integrated by a computer attached to the EPR spectrometer to obtain the area intensity, and then the concentration of spin adduct was calculated using the ratio of these areas.

\subsection{Ascorbate content $\left(A H^{-}\right)$}

The ascorbate content was measured according to Foyer et al. (1983). Digestive glands were homogenized in $10 \%(\mathrm{w} / \mathrm{v})$ metaphosphoric acid. The acid extracts were neutralized with $1.25 \mathrm{M} \mathrm{K}_{2} \mathrm{CO}_{3}$, and the amounts of ascorbate were determined by addition of $5 \mathrm{U} / \mathrm{mL}$ ascorbate oxidase. Ascorbate (Sigma) was used as standard.

\section{5. $A^{\circ} / A H^{-}$ratio as an index of hydrophilic oxidative stress}

The $\mathrm{A}^{*} / \mathrm{AH}^{-}$ratio was previously used as an index of hydrophilic oxidative stress in biological systems (Galleano et al., 2002). $\mathrm{A}^{-}$is formed by $\mathrm{AH}^{-}$oxidation, which can be mediated by metal catalysts such as iron and copper (Martell, 1982) as described in reaction 1 .

$\mathrm{AH}^{-}+\mathrm{Fe}^{3+} \rightarrow \mathrm{A}^{\cdot}+\mathrm{Fe}^{2+}$

(reaction 1$)$

$\frac{\mathrm{d}\left[\mathrm{A}^{*}\right]}{\mathrm{d} t}=k_{1}\left[\mathrm{Fe}^{3+}\right]\left[\mathrm{AH}^{-}\right]$

The estimated value for the rate constant at $25^{\circ} \mathrm{C}\left(k_{1}\right)$ is $30 \mathrm{M}^{-1} \mathrm{~s}^{-1}$ (Roginsky and Stegmann, 1994) calculated for the reaction of $\mathrm{AH}^{-}$with $\mathrm{Fe}(\mathrm{III}) \mathrm{EDTA}$. Self-disproportionation has been postulated as the main or even the only way for $\mathrm{A}^{*}$ decay in biological systems (Roginsky and Stegmann, 1994) (reaction 2).

$2 \mathrm{~A}^{\cdot} \rightarrow \mathrm{AH}^{-}+\mathrm{DHA}$

(reaction2)

$\frac{-\mathrm{d}\left[\mathrm{A}^{*}\right]}{\mathrm{d} t}=2 k_{2}\left[\mathrm{~A}^{\bullet}\right]^{2}$

The rate constant $k_{2}$ at $25^{\circ} \mathrm{C}$ has been estimated as $210^{6}$ $\mathrm{M}^{-1} \mathrm{~s}^{-1}$ (Roginsky and Stegmann, 1994). Under steady state condition for $\mathrm{A}^{\cdot}$ the rate of generation of $\mathrm{A}^{*}$ should be identical to the rate of decay of $\mathrm{A}^{\circ}$, thus

$\frac{\mathrm{d}\left[\mathrm{A}^{*}\right]}{\mathrm{d} t}=\frac{-\mathrm{d}\left[\mathrm{A}^{*}\right]}{\mathrm{d} t}=2 k_{2}\left[\mathrm{~A}^{*}\right]^{2}$

\subsection{Quantification of lipid radicals by electron paramagnetic resonance (EPR)-spin trapping}

Homogenates were prepared in potassium phosphate buffer ( $\mathrm{pH}$ 7.4) containing $50 \mathrm{mM} \alpha$-(4-pyridyl 1-oxide)- $N$ - $t$-butyl nitrone $(\mathrm{POBN})$. EPR spectra were obtained at room temperature using a Bruker spectrometer ECS 106, operating at $9.81 \mathrm{GHz}$ with $50 \mathrm{kHz}$ modulation frequency. EPR instrument settings for the spin trapping experiments were: microwave power $20 \mathrm{~mW}$, modulation amplitude $1.194 \mathrm{G}$, time constant $81.92 \mathrm{~ms}$, and receiver gain, $210^{4}$ (Jurkiewicz and Buettner, 1994). Quantification was performed according to Kotake et al. (1996).

\subsection{Iron content}

Isolated digestive glands were dried to constant weight at $60^{\circ} \mathrm{C}$ over $48 \mathrm{~h}$, before digesting with $\mathrm{HClO}_{4}: \mathrm{HNO}_{3}(1: 1)$ solution. Concentrations of iron in the extracts were measured spectrophotometrically after reduction with thioglycolic acid, and the addition of bathophenanthroline (4,7-diphenyl-1,10phenanthrolinedisulfonic acid) (Brumby and Massey, 1967).

\subsection{Enzyme assays}

Homogenates from digestive glands were prepared in $50 \mathrm{mM}$ potassium phosphate- $120 \mathrm{mM} \mathrm{KCl}(\mathrm{pH}=7.4)$. Total SOD activity (EC 1.15.1.1) was determined according to Misra and Fridovich (1972). Catalase activity (EC 1.11.1.6) was assayed spectrophotometrically by the decomposition of $\mathrm{H}_{2} \mathrm{O}_{2}$ at $240 \mathrm{~nm}$ in a reaction mixture consisting of $50 \mathrm{mM}$ potassium phosphate buffer $(\mathrm{pH} 7.0)$ containing $1 \%$ Triton-X100, $1: 9(\mathrm{w} / \mathrm{v})$ and $12.5 \mathrm{mM}$ $\mathrm{H}_{2} \mathrm{O}_{2}$ (Aebi, 1984). Glutathione peroxidase activity (GPx) was assayed according to Lawrence and Burk (1976) using cumene hydroperoxide as substrate. All enzymatic activities were assessed at $25^{\circ} \mathrm{C}$.

\subsection{Total thiol content}

Homogenates from digestive glands were prepared in $50 \mathrm{mM}$ potassium phosphate, $120 \mathrm{mM} \mathrm{KCl}(\mathrm{pH}=7.4)$. Total thiol content was assayed according to Sedlak and Lindsay (1968), employing 5,5'-dithiobis (2-nitrobenzoic acid) (DTNB) and measuring absorbance at $412 \mathrm{~nm}$, using glutathione as standard.

\subsection{Content of lipid soluble antioxidants}

The content of $\alpha$-tocopherol and $\beta$-carotene in the digestive gland homogenates was quantified by reverse-phase HPLC with electrochemical detection using a Bioanalytical Systems LC-4C amperometric detector with a glassy carbon working electrode at an applied oxidation potential of 0.6V (Desai, 1984). Samples were extracted with $1 \mathrm{~mL}$ of ethanol and $4 \mathrm{~mL}$ of hexane. After centrifugation at $600 \times g$ for $10 \mathrm{~min}$, the hexane phase was removed and evaporated to dryness under $\mathrm{N}_{2}$. Extracts were dissolved in methanol/ethanol $(1: 1)$ and injected for HPLC analysis (Desai, 1984). D,L- $\alpha$-Tocopherol (Sigma) and $\beta$-carotene (Sigma) were used as standards. Total protein content was assessed according to Bradford (1976) and BSA (Sigma) was used as standard.

\subsection{Nitrite $\left(\mathrm{NO}_{2}^{-}\right)$content}

Homogenates from digestive glands were prepared in $50 \mathrm{mM}$ potassium phosphate, $120 \mathrm{mM} \mathrm{KCl}, \mathrm{pH} 7.4$. Aliquots from the homogenates were treated with ethanol 95\% (w/v) (Miranda et 
Table 2

Seasonal variations in enzymatic antioxidants in digestive glands from $N$. (P.) magellanica

\begin{tabular}{lcll}
\hline Season & $\begin{array}{l}\text { SOD } \\
\left(\mathrm{U} \mathrm{mg} \mathrm{m}^{-1} \mathrm{FW}\right)\end{array}$ & $\begin{array}{l}\text { CAT } \\
\left(\mathrm{U} \mathrm{mg}^{-1} \mathrm{FW}\right)\end{array}$ & $\begin{array}{l}\mathrm{GPx} \\
\left(\mathrm{U} \mathrm{mg}^{-1} \mathrm{FW}\right)\end{array}$ \\
\hline Winter (July 2002) & $0.42 \pm 0.06$ & $2.9 \pm 0.2^{\mathrm{a}}$ & $9 \pm 2^{\mathrm{a}}$ \\
Spring (October 2002) & $0.30 \pm 0.01$ & $4.3 \pm 0.8^{\mathrm{b}}$ & $53 \pm 12^{\mathrm{b}}$ \\
Summer (January 2003) & $0.31 \pm 0.05$ & $7 \pm 1^{\mathrm{b}}$ & $40 \pm 8^{\mathrm{b}}$ \\
Fall (April 2003) & $0.4 \pm 0.2$ & $5.8 \pm 0.5^{\mathrm{b}}$ & $\mathrm{nd}$ \\
Winter (July 2003) & $0.36 \pm 0.08$ & $3.1 \pm 0.4^{\mathrm{a}}$ & $\mathrm{nd}$ \\
\hline
\end{tabular}

Data are expressed as means SEM of 6 independent experiments.

${ }^{\mathrm{a}, \mathrm{b}}$ Values followed by the letter $(\mathrm{b})$ are significantly different $(p<0.05)$ from values in winter samples (a).

nd: non determined.

$\mathrm{FW}=$ fresh mass.

al., 2001) and centrifuged at $2500 \times g$ for $10 \mathrm{~min}$. The content of $\mathrm{NO}_{2}^{-}$was determined according to Andronik-Lion et al. (1992). A standard solution of $\mathrm{NaNO}_{2}$ (Merck) was used for quantification.

\subsection{Nitric oxide (NO) content}

The digestive glands were homogenized in $100 \mathrm{mM}$ potassium phosphate buffer $120 \mathrm{mM} \mathrm{KCl}(\mathrm{pH} 7.4)$ and $10 \mathrm{mM} \mathrm{N}$ methyl-D-glucamine-dithiocarbamate iron (MGD-Fe) as spin trap. EPR spectra were obtained at room temperature using a Bruker spectrometer ECS 106, operating at $9.81 \mathrm{GHz}$ with $50 \mathrm{kHz}$ modulation frequency. EPR instrument settings for the spin trapping experiments were: microwave power $20 \mathrm{~mW}$, modulation amplitude $5.983 \mathrm{G}$, time constant, $20.48 \mathrm{~ms}$, and receiver gain $110^{5}$ (Kalyanaraman, 1996). Quantification was performed as previously described by Kotake et al. (1996).

\subsection{Statistical analyses}

Data in the text and tables are expressed as mean \pm S.E.M. of six independent experiments, with two replicates in each experiment. Statistical tests were carried out using Statview for Windows, ANOVA, SAS Institute Inc., version 5.0, employing Student-Newman test.

Table 3

Content of non-enzymatic antioxidants in the lipid fraction and total thiol tissue content in digestive glands from $N$. (P.) magellanica

\begin{tabular}{llll}
\hline Season & $\begin{array}{l}\alpha \text {-tocopherol } \\
\text { (nmol mg }\end{array}$ & $\begin{array}{l}\beta \text {-carotene } \\
\left(\mathrm{nmol} \mathrm{mg} \mathrm{mp}^{-1} \text { prot) }\right.\end{array}$ & $\begin{array}{l}\text { Total thiols } \\
\left(\mathrm{nmol} \mathrm{mg}{ }^{-1} \mathrm{FW}\right)\end{array}$ \\
\hline Winter (July 2002) & $2.7 \pm 0.4^{\mathrm{a}}$ & $5.2 \pm 0.6^{\mathrm{a}}$ & $0.09 \pm 0.02^{\mathrm{a}}$ \\
Spring (October 2002) & $1.6 \pm 0.8^{\mathrm{a}}$ & $17 \pm 6^{\mathrm{b}}$ & $0.16 \pm 0.05^{\mathrm{b}}$ \\
Summer & $3.5 \pm 0.2^{\mathrm{b}}$ & $7.4 \pm 0.9^{\mathrm{b}}$ & $0.19 \pm 0.01^{\mathrm{b}}$ \\
$\quad \begin{array}{l}\text { (January 2003) } \\
\text { Fall (April 2003) }\end{array}$ & $4.8 \pm 0.8^{\mathrm{b}}$ & $8 \pm 2^{\mathrm{b}}$ & $0.15 \pm 0.05^{\mathrm{b}}$ \\
Winter (July 2003) & $1.3 \pm 0.8^{\mathrm{a}}$ & $8 \pm 2^{\mathrm{b}}$ & $\mathrm{nd}$ \\
\hline
\end{tabular}

Data are expressed as means SEM of 6 independent experiments.

${ }^{\mathrm{a}, \mathrm{b}}$ Values followed by the letter (b) are significantly different $(p<0.05)$ from values in winter samples (a).

nd: non determined.

prot $=$ protein

$\mathrm{FW}=$ fresh mass.

\section{Results}

Nacella (P.) magellanica limpets from Beagle Channel displayed no significant changes in body fresh weight over length index $\left(I_{\mathrm{w} / 1}\right.$, Table 1$)$ in the studied period. Respiration rates (Table 1) were maximal in the beginning of summer (January) when the main spawning event takes place, and water temperatures reach their yearly maximum. Moreover, oxygen uptake was significantly increased over the very low winter rates during the entire rest of the year. Low winter metabolic rates are likely to be associated with low winter water temperatures of $3{ }^{\circ} \mathrm{C}$ found in the intertidal of Beagle Channel (Malanga et al., 2004).

Total SOD activity did not show any significant seasonal dependency. However, catalase activity was higher (141\%) during summer, spring and fall, than winter, while summer GPx activity showed a 3 -fold increase over winter values (Table 2). The concentrations of the non enzymatic antioxidants $(\alpha-$ tocopherol, $\beta$-carotene and total thiols) were significantly lower during winter than summer. More specifically, the total thiol concentration in spring was double that of winter levels, while $\beta$-carotene content was around three-times higher (Table 3).

A typical EPR spectrum of ascorbyl radical (A') in digestive gland from $N$. (P.) magellanica, was observed with the characteristic two lines at $g=2.005$ and $a_{\mathrm{H}}=1.8 \mathrm{G}$, in accordance with computer spectral simulated signals obtained using the parameters given in the Materials and methods section (Fig. 1 d). EPR spectrum of $\mathrm{A}^{*}$ is lower in digestive glands
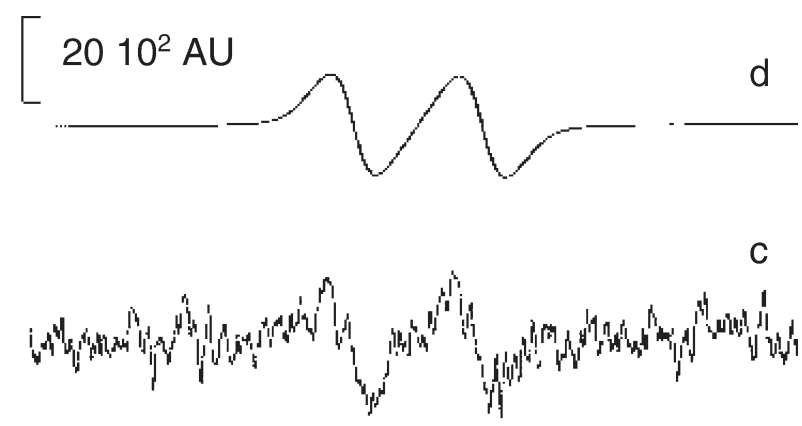

b

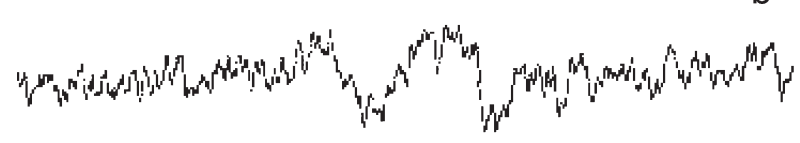

a

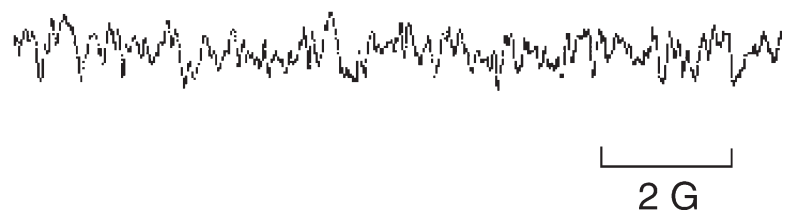

Fig. 1. EPR detection of ascorbyl radical in digestive glands from Nacella (P.) magellanica. (a) EPR spectra of dimethylsulfoxide, (b) typical EPR spectra of digestive gland from July (winter) 2002, (c) typical EPR spectra of digestive gland from April (fall) 2003, and (d) computer-simulated spectrum employing the following spectral parameters, $g=2.005$ and $a_{\mathrm{H}}=1.8 \mathrm{G}$, are shown. 
Table 4

Ascorbyl radical content/ascorbate content ratio in digestive glands of $N$. (P.) magellanica

\begin{tabular}{lclc}
\hline Season & $\begin{array}{l}\mathrm{A}^{\cdot} \text { content } \\
\left(\mathrm{pmol} \mathrm{mg} \mathrm{m}^{-1} \mathrm{FW}\right)\end{array}$ & $\begin{array}{l}\mathrm{AH}^{-} \text {content } \\
\left(\mathrm{nmol} \mathrm{mg} \mathrm{m}^{-1} \mathrm{FW}\right)\end{array}$ & $\begin{array}{l}\mathrm{A}^{\cdot} / \mathrm{AH}^{-} \\
\left(10^{-5} \mathrm{AU}\right)\end{array}$ \\
\hline Winter (July 2002) & $1.1 \pm 0.6^{\mathrm{a}}$ & $30 \pm 3^{\mathrm{a}}$ & $3.7 \pm 0.2^{\mathrm{a}}$ \\
Spring (October 2002) & $5 \pm 1^{\mathrm{b}}$ & $15 \pm 2^{\mathrm{b}}$ & $32 \pm 5^{\mathrm{b}}$ \\
Summer (January 2003) & $3 \pm 1^{\mathrm{b}}$ & $17 \pm 2^{\mathrm{b}}$ & $18 \pm 5^{\mathrm{b}}$ \\
Fall (April 2003) & $5 \pm 2^{\mathrm{b}}$ & $11 \pm 3^{\mathrm{b}}$ & $45 \pm 6^{\mathrm{b}}$ \\
Winter (July 2003) & $1.7 \pm 0.4^{\mathrm{a}}$ & $28 \pm 4^{\mathrm{a}}$ & $6 \pm 2^{\mathrm{a}}$ \\
\hline
\end{tabular}

Data are expressed as means SEM of 6 independent experiments.

${ }^{\mathrm{a}, \mathrm{b}}$ Values followed by the letter (b) are significantly different $(p<0.05)$ from values in winter samples (a).

$\mathrm{FW}=$ fresh mass.

isolated from molluscs in winter than spring (Fig. 1a). DMSO itself was examined and no DMSO spin adduct was observed (Fig. 1 a). $A^{\cdot}$ content, assessed by quantification of EPR signals, was significantly lower (2.73 fold) in winter as compared to summer (Table 4). The $\mathrm{A} / \mathrm{AH}^{-}$ratio was significantly lower (4.9 fold) on the digestive gland of the intertidal $N$. (P.) magellanica during winter as compared to the rest of the year (Table 4$)$.

EPR analysis of digestive glands of $N$. (P.) magellanica during winter and summer was performed with homogenates supplemented with the spin trap MGD-Fe, to assess NO content.
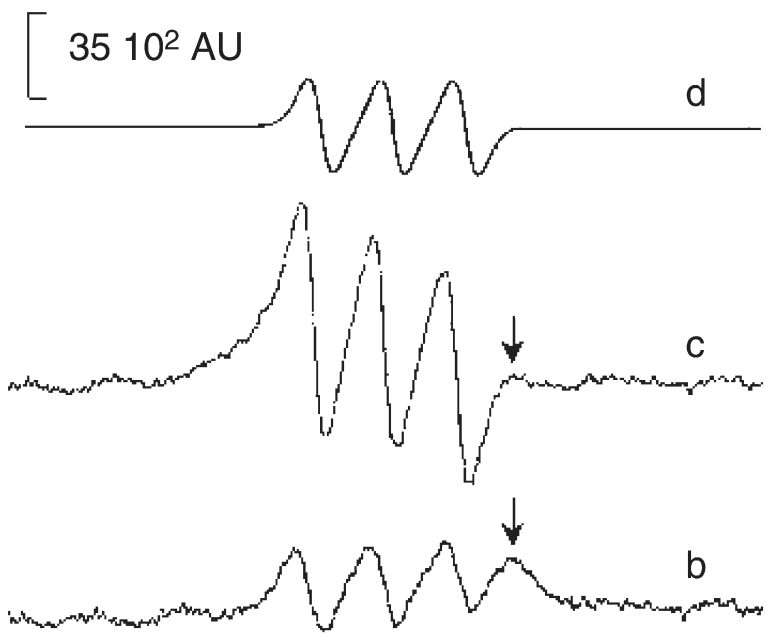

a

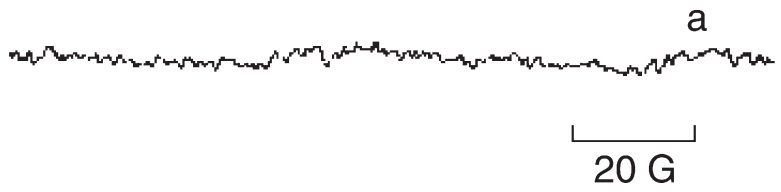

Fig. 2. Typical EPR spectra of the Fe-MGD-NO spin adduct in digestive glands from Nacella (P.) magellanica. (a) spectra of $N$-methyl-D-glucaminedithiocarbamate-iron (MGD-Fe) itself, (b) typical EPR spectra of digestive gland in July (winter) 2002, (c) typical EPR spectra of digestive gland in April (fall) 2003, and (d) computer-simulated EPR spectra using the parameters, $g=2.03$ and $a_{\mathrm{N}}=12.5 \mathrm{G}$, are shown. The arrow $(\downarrow)$ indicates the spectrum of the $\left[(\mathrm{MGD})_{2} / \mathrm{Cu}\right]$ complex.
Table 5

Seasonal variation in NO and nitrite content in digestive glands of $N .(P$. magellanica

\begin{tabular}{lll}
\hline Season & $\begin{array}{l}\text { NO content } \\
\left(\mathrm{pmol} \mathrm{mg}^{-1} \mathrm{FW}\right)\end{array}$ & $\begin{array}{l}\text { Nitrite content } \\
\left(\mathrm{nmol} \mathrm{mg} \mathrm{m}^{-1} \mathrm{FW}\right)\end{array}$ \\
\hline Winter (July 2002) & $491 \pm 115^{\mathrm{a}}$ & $1.6 \pm 0.2^{\mathrm{a}}$ \\
Spring (October 2002) & $433 \pm 97^{\mathrm{a}}$ & $2.5 \pm 0.6^{\mathrm{b}}$ \\
Summer (January 2003) & $768 \pm 90^{\mathrm{b}}$ & $2.1 \pm 0.2^{\mathrm{b}}$ \\
Fall (April 2003) & $698 \pm 148^{\mathrm{a}}$ & $3.3 \pm 0.7^{\mathrm{b}}$ \\
Winter (July 2003) & $499 \pm 136^{\mathrm{a}}$ & $\mathrm{nd}$ \\
\hline
\end{tabular}

Data are expressed as means SEM of 6 independent experiments.

${ }^{\mathrm{a}, \mathrm{b}}$ Values followed by the letter $(\mathrm{b})$ are significantly different $(p<0.05)$ from values in winter samples (a).

nd: non determined.

$\mathrm{FW}=$ fresh mass.

Data in Fig. 2 shows a characteristic EPR signal for the adduct Fe-MGD-NO $\left(g=2.03\right.$ and $\left.a_{\mathrm{N}}=12.5 \mathrm{G}\right)$ in the homogenates from digestive glands of winter (Fig. 2 b) and summer animals (Fig. 2 c). The spectrum obtained from $N$. (P.) magellanica homogenates showed a broad signal indicated by an arrow in traces in Fig $2(b, c)$, that could be part of the EPR spectrum of the $\left[(\mathrm{MGD})_{2} / \mathrm{Cu}\right]$ complex, resulting from the chelation of copper. Quantification of the EPR signal showed significantly higher content of the Fe-MGD-NO adduct in digestive glands in summer over winter (Table 5). These data are consistent with
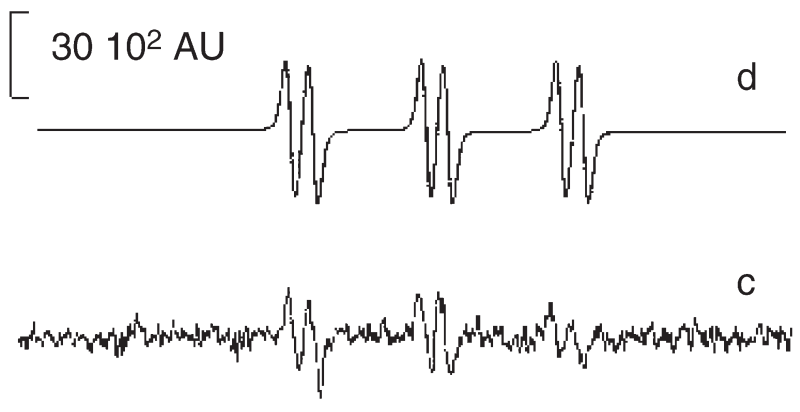

b

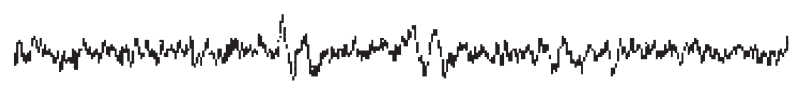

a

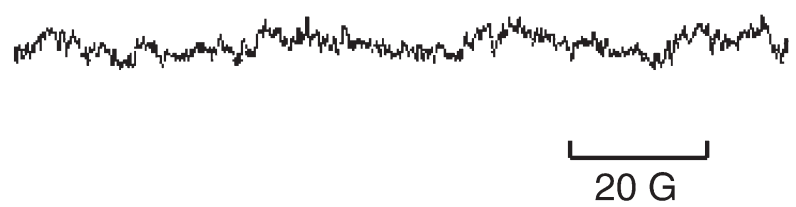

Fig. 3. EPR detection of lipid radicals in digestive glands from Nacella $(P$. magellanica. (a) EPR spectra of $\alpha$-(4-pyridyl 1-oxide)- $N$-t-butyl nitrone (POBN) itself, (b) typical EPR spectra of digestive gland from July (winter) 2002, (c) typical EPR spectra of digestive gland from April (fall) 2003, and (d) computer-simulated EPR spectra exhibiting hyperfine splittings that are characteristic of POBN/lipid radicals, $a_{\mathrm{N}}=15.56 \mathrm{G}$ and $a_{\mathrm{H}}=2.79 \mathrm{G}(\mathrm{d})$, are shown. 
Table 6

Seasonality of lipid peroxidation and iron content in digestive glands from $N$. (P.) magellanica

\begin{tabular}{lll}
\hline Season & $\begin{array}{l}\text { Lipid radical content } \\
\left(\mathrm{pmol} \mathrm{mg} \mathrm{m}^{-1} \mathrm{FW}\right)\end{array}$ & $\begin{array}{l}\text { Iron content } \\
\left(\mathrm{nmol} \mathrm{mg} \mathrm{m}^{-1} \mathrm{FW}\right)\end{array}$ \\
\hline Winter (July 2002) & $122 \pm 29^{\mathrm{a}}$ & $0.99 \pm 0.07^{\mathrm{a}}$ \\
Spring (October 2002) & $358 \pm 30^{\mathrm{b}}$ & $2.1 \pm 0.6^{\mathrm{b}}$ \\
Summer (January 2003) & $204 \pm 29^{\mathrm{b}}$ & $2.7 \pm 0.6^{\mathrm{b}}$ \\
Fall (April 2003) & $314 \pm 45^{\mathrm{b}}$ & $1.8 \pm 0.2^{\mathrm{b}}$ \\
Winter (July 2003) & $\mathrm{nd}$ & $0.9 \pm 0.1^{\mathrm{a}}$ \\
\hline
\end{tabular}

Data are expressed as means SEM of 6 independent experiments.

${ }^{\mathrm{a}, \mathrm{b}}$ Values followed by the letter $(\mathrm{b})$ are significantly different $(p<0.05)$ from values in winter samples (a).

nd: non determined.

$\mathrm{FW}=$ fresh mass.

the profile of the nitrite content in the digestive glands over the year (Table 5).

As an estimation of oxidative stress in the lipid phase, lipid peroxidation in the digestive gland was assessed by EPR as the tissue content of lipid radicals. Lipid radicals in the digestive gland combined with the spin trap POBN resulted in adducts that gave a characteristic EPR spectrum with hyperfine coupling constants of $a_{\mathrm{N}}=15.56 \mathrm{G}$ and $a_{\mathrm{H}}=2.79 \mathrm{G}$ (Fig. $3 \mathrm{~b}, \mathrm{c}$ ), in concordance with computer spectral simulated signals obtained using the overall mentioned parameters (Fig. 3 d). POBN itself was examined and no POBN spin adduct was observed (Fig. 3 a). However, bulk lipid radical content in limpet digestive gland was significantly lower $(67 \%)$ in winter than summer (Table 6). The total content of iron in digestive gland extracts was $270 \%$ lower in winter as compared to values measured in summer (Table 6).

\section{Discussion}

\subsection{Seasonality of limpets metabolic activity}

A significant reduction of ash free dry weight during the winter month (July-October) was reported for the Antarctic limpets, Nacella concinna by Fraser et al. (2002). Considering the early spawning time in spring, this presumably supports gonad development. For subtidal specimens of the Antarctic limpet Nacella concinna sampled in $6-15 \mathrm{~m}$ water depth at Rothera, Adelaide Island, Antarctic Peninsula, Fraser et al. (2002) also reported continued feeding activity in winter; however, at significantly reduced rates compared to summer values. Further, our data demonstrated elevated aerobic metabolic rates in $N$. (P.) magellanica in early spring (October) and throughout the warmer seasons, summer and fall (Table 1). Summer metabolic rates increased by approximately 3 -fold over winter values. This means that although body mass per shell length is maintained during the winter, the animals enter a state of metabolic downregulation. Presumably, in addition to a low winter food intake, the constant body mass in winter is achieved by a reduction in the metabolic costs for locomotory activity and growth, which manifests itself in lower winter oxygen uptake rates. Importantly, however, metabolic activity in Beagle Channel limpets is already high in early spring (October), whereas the
October values in Antarctic limpets from Rothera were even beneath winter metabolic rates (Fraser et al., 2002). This indicates that in Subantarctic $N$. (P.) magellanica the onset of metabolic up-regulation during spring occurs much more rapidly and is also more pronounced, compared to subtidal Nacella concinna in the Antarctic waters around Rothera, probably due to the fact that the significant temperature changes at higher latitudes. Firstly, there is no winter ice cover in the Beagle Channel intertidal. Secondly, water temperatures of $8^{\circ} \mathrm{C}$ are reached in early spring (October) in the Beagle Channel, and may represent an early spawning cue for $N$. (P.) magellanica. Whereas water temperature at Rothera have not rises from winter values by October. Also, a more rapid increase in day length and radiation intensity at Ushuaia may affect feeding activity of the intertidal limpets, inducing metabolic rates to rise after winter. In the Beagle Channel an important increase of phytoplankton biomass occurs at the end of September/beginning of October (M. Hernando personal communication).

\subsection{Enzymatic and non-enzymatic antioxidants}

The pronounced increase of metabolic activity in spring is accompanied by an increase not only in enzymatic antioxidants, e.g. GPx, but also the lipid soluble antioxidant capacity and in particular $\beta$-carotene tissue levels. $\beta$-Carotene is a reliable marker of the onset of feeding activity, because carotenoids cannot be synthesized by animals and, therefore, have to be sequestered from algal food. Campbell (1969) observed carotenoid peaks in Mytilus edulis in spring and fall, corresponding to phytoplankton blooms and the mussels reproductive cycle. Assimilation of dietary carotenoids into marine animal tissues and especially into eggs is found in many taxa (Marsh et al., 1990). It is important ensuring antioxidant and photo-protection of eggs and pelagic larvae. Unaltered SOD activities upon seasonal warming, as seen in $N$. (P.) magellanica, have previously been observed in the horse clam Modiolus modiolus (Lesser and Kruse, 2004). Glutathione metabolizing enzymes and thiol concentrations increased in summer in Nacella, in a similar manner in Helix aspersa (Ramos-Vasconcelos et al., 2005). Higher GPx activity at spring and summer could lead to an active consumption of GSH to detoxify $\mathrm{H}_{2} \mathrm{O}_{2}$. However, since the system GSH/GPx should be a key candidate for exerting oxidative control in the hydrophilic media, the cell seems to response increasing significantly the content of the substrate (thiols) to fulfil its antioxidant role. As the glutathione system is an important buffer for the cellular redox potential, the strong increase in GPx activity and cellular thiols in $N$. (P.) magellanica in early spring may represent a response to vastly enhanced metabolic ROS formation during the animals transition from low winter metabolism to higher summer levels.

\subsection{Oxidative stress index in subantarctic limpets}

The cellular content of catalytically active labile iron could be estimated as $1 \%$ of the total iron content (Table 6) (Kakhlon and Cabantchik, 2002). According to Eq. (1) (Materials and methods section) and employing the values of $\mathrm{AH}^{-}$content 
(Table 4), the rate of generation of $\mathrm{A}^{\cdot}$ was estimated as $910^{-6} \mathrm{M}$ $\mathrm{s}^{-1}$ and $1410^{-6} \mathrm{M} \mathrm{s}^{-1}$ in $N$. (P.) magellanica digestive glands isolated in winter and summer, respectively. According to Eq. (3) (Materials and methods section), the estimated values for $k_{2}$ and the generation rate of $\mathrm{A}^{*}$ calculated above, the steady state concentration of $\mathrm{A}^{\cdot}$ might be 1.5 and $2 \mu \mathrm{M}$ for winter and summer, respectively. The data reported here for $\mathrm{A}^{*}$ steady state concentrations measured by EPR, are $1.1 \pm 0.6$ and $3 \pm 1 \mu \mathrm{M}$ for digestive glands isolated during winter and summer, respectively. Thus, the simple kinetic model shown above seems to reflect appropriately the main reactions involved in ascorbate metabolism under physiological conditions and supports the view that oxidative stress in limpets in vivo underlies seasonal fluctuations of the environment. Moreover, the lower index of oxidative stress observed in winter is in agreement with lower winter oxygen uptake rates in the limpets, indicating that ROS production in the digestive gland follows the overall animal oxygen turnover.

On the other hand, the overall mechanism that describes the pathways involved in the ascorbate metabolism seems to strongly dependent on: (a) the way the cellular non-constitutive iron is stored and (b) how high over physiological values the amount of catalytically active iron forms have to be in digestive gland tissue, before significant interaction occurs with other cellular components. Also, lower values of lipid peroxidation in winter time could be due to the combined effects of lower metabolic radical production and lower iron uptake in winter.

The increase of metabolic rates in summer result it higher levels of ROS formation in $N$. (P.) magellanica, which can only in part be neutralized by the antioxidant defense systems. The reaction of ascorbate with $\alpha$-tocopheroxyl radical $\left(\alpha-\mathrm{T}^{*}\right)$ results in recycling of $\alpha$-tocopherol $(\alpha-\mathrm{TH})$ molecules, Buettner (1993) have demonstrated the close association between lipid and water soluble antioxidants (reaction 3)

$$
\mathrm{AH}^{-}+\alpha-\mathrm{T}^{\cdot} \rightarrow \mathrm{A}^{\cdot}+\alpha-\mathrm{TH}
$$

(reaction3)

For the lipophilic compartment, the ratio lipid radical content/ $\alpha$-TH can be understood as an indicator of the balance between free radical damage and antioxidant protection. This index can be obtained from data in Table 3 (lipid soluble antioxidants) and in Table 6 (lipid radical content). The index was $1.5 \pm 0.4$ and $2.5 \pm$ 0.6 for winter and summer digestive gland tissue, respectively. Thus, the onset of oxidative stress during early spring affects both, the water and lipid phases of the digestive gland tissue. It is important to point out, as it was reported by Brazao et al. (2003), that the environmental conditions to which the limpets are submitted in particular the diet, affect their lipid composition, that could alter lipid radical generation. Seasonal changes not only affect ROS generation but also reactive nitrogen species (RNS) formation as well, since the NO content also increased in summer in comparison to winter in limpet digestive glands. $\mathrm{O}_{2}^{-}$plays a key role in the interaction between ROS and RNS, since through the reaction with $\mathrm{NO}$, peroxynitrite $\left(\mathrm{ONOO}^{-}\right)$is generated at a rate close to diffusion, and $\mathrm{ONOO}^{-}$acts as both a nitrating agent and powerful oxidant capable of modifying proteins (formation of nitrotyrosine), lipids (lipid oxidation, lipid nitration) and nucleic acids (DNA oxidation and DNA nitration) (Gisone et al., 2004). Thus, seasonal-dependent simultaneous increase in ROS and RNS may drastically enhance potential cellular damage. On the other hand, if either of the mentioned species were intended to act as signaling molecules, the reaction to $\mathrm{ONOO}^{-}$could act to suppress the signal.

Taken as a whole, the data presented the effect of the rapid seasonal onset of high metabolic activity on oxidative stress parameters, including oxygen and nitrogen active radical species in Subantarctic intertidal limpets. Both, oxygen and nitrogen radical generation rates in $N$. (P.) magellanica were clearly elevated in summer, when water temperatures and the metabolic activity of the limpets were significantly higher. There was no significant difference in spring, summer and fall animals were compared either metabolic rate or any oxidative stress parameter when which is consistent with the uniformity of the water temperature throughout this period. Although long daytime light duration and higher food availability in early spring may also trigger elevated activity in $N$. (P.) magellanica, and probably spawning. The results highlight the need to take into account the seasonal variations of oxidative stress conditions in $N$. (P.) magellanica when analyzing other stress effects, such as contamination.

\section{Acknowledgments}

This study was supported by grants from the University of Buenos Aires (B017), SECyT-DLR International Bureau (ARG 99/010), ANPCyT (PICT 11817), Fundación Antorchas and CONICET. S.P. J.C. and G.M. are career investigator from CONICET, M.S.E. is a fellow from the University of Buenos Aires. The authors are grateful to D. Aureliano and M. Gutierrez for technical assistance.

\section{References}

Abele, D., Puntarulo, S., 2004. Formation of reactive species and induction of antioxidant defence systems in polar and temperate marine invertebrates and fish. Comp. Biol. Physiol., A 138, 405-415.

Abele-Oeschger, D., Oeschger, R., Theede, H., 1994. Biochemical adaptations of Nereis diversicolor (Polychaeta) to temporarily increased hydrogen peroxide levels in intertidal sandflats. Mar. Ecol., Prog. Ser. 106, 101-110.

Aebi, H., 1984. Catalase in vitro. Methods Enzymol. 105, 121-126.

Ahmad, T.A., Chaplin, A.E., 1979. Seasonal variations in the anaerobic metabolism of the mussel Mytilus edulis (L.). Comp. Biochem. Physiol., B 64, 351-356.

Ahn, I.Y., Kim, K.W., Choi, H.J., 2002. A baseline study on metal concentrations in the Antarctic limpet Nacella concinna (Gastropoda: Patellidae) on King George Island: variations with sex and body parts. Mar. Pollut. Bull. 44, 424-431.

Ahn, I.Y., Chung, K.H., Choi, H.J., 2004. Influence of glacial runoff on baseline metal accumulation in the Antarctic limpet Nacella concinna from King George Island. Mar. Pollut. Bull. 49, 119-127.

Andronik-Lion, V., Boucher, J.L., Delaforge, M., Henry, Y., Mansuy, D., 1992. Formation of nitric oxide by cytochrome P450-catalyzed oxidation of aromatic amidoximes. Biochem. Biophys. Res. Commun. 185, 452-458.

Bradford, M.M., 1976. A rapid and sensitive method for the quantitation of microgram quantities of protein utilizing the principle of protein-dye binding. Anal. Biochem. 72, 248-254.

Brazao, S., Morais, S., Boaventura, D., Ré, P., Narciso, L., Hawkins, S.J., 2003. Spatial and temporal variation of the fatty acid composition of Patella spp. (Gastropoda: Prosobranchia) soft bodies and gonads. Comp. Biochem. Physiol., B 136, 425-441. 
Brockington, S., Peck, L.S., 2001. Seasonality of respiration and ammonium excretion in the Antarctic echinoid Sterechinus neumayeri. Mar. Ecol., Prog. Ser. 219, 159-168.

Brockington, S., Clarke, A., 2001. The relative influence of temperature and food on the metabolism of a marine invertebrate. J. Exp. Mar. Biol. Ecol. 258, 87-99.

Brumby, P.E., Massey, V., 1967. Determination of nonheme iron, total iron, and copper. Methods Enzymol. 10, 463-472.

Buettner, G.R., 1993. The pecking order of free radicals and antioxidants: lipid peroxidation, $\alpha$-tocopherol, and ascorbate. Arch. Biochem. Biophys. 300, 535-543.

Campbell, S.A., 1969. Seasonal cycles in the carotenoid content in Mytilus edulis. Mar. Biol. 4, 227-232.

Desai, I., 1984. Vitamin E analysis methods for animal tissues. Methods Enzymol. 105, 138-146.

Foyer, C., Rowell, J., Walker, D., 1983. Measurement of the ascorbate content of spinach leaf protoplasts and chloroplasts during illumination. Planta 157, 239-244.

Fraser, K.P.P., Clarke, A., Peck, L.S., 2002. Feast and famine in Antarctica: seasonal physiology in the limpet Nacella concinna. Mar. Ecol., Prog. Ser. 242, 169-177.

Galleano, M., Aimo, L., Puntarulo, S., 2002. Ascorbyl radical/ascorbate ratio in plasma from iron overloaded rats as oxidative stress indicator. Toxicol. Lett. 133, 193-201.

Geracitano, L.A., Monserrat, J.M., Bianchini, A., 2004. Oxidative stress in Laeonereis acuta (Polychaeta Nereididae): environmental and seasonal effects. Mar. Environ. Res. 58, 625-630.

Gisone, P., Dubner, D., Pérez, M.R., Michelin, S., Puntarulo, S., 2004. The role of nitric oxide in the radiation-induced effects in the developing brain. In Vivo 18, 281-292.

Giulivi, C., Cadenas, E., 1993. The reaction of ascorbic acid with different heme iron redox states of myoglobin. FEBS Lett. 332, 287-290.

Heilmayer, O., Brey, T., Storch, D., Mackensen, A., Arntz, W.E., 2005. Population dynamics and metabolism of Aequipecten opercularis (L.) from the western English Channel (Roscoff, France). J. Sea Res. 52, 33-44.

Jurkiewicz, B.A., Buettner, G.R., 1994. Ultraviolet light-induced free radical formation in skin: an electron paramagnetic resonance study. Photochem. Photobiol. 59, 1-4.

Kakhlon, O., Cabantchik, Z.I., 2002. The labile iron pool: characterization, measurement, and participation in cellular processes. Free Radic. Biol. Med. 33, 1037-1046.

Kalyanaraman, B., 1996. Detection of nitric oxide by electron spin resonance in chemical, photochemical, cellular, physiological, and pathophysiological systems. Methods Enzymol. 268, 168-187.

Keller, M., Sommer, A., Pörtner, H.O., Abele, D., 2004. Seasonality of energetic functioning and reactive oxygen species production by mitochondria of the lugworm Arenicola marina, exposed to acute temperature changes. J. Exp. Biol. 207, 2529-2538.

Kirchin, M.A., Wiseman, A., Livingstone, D.R., 1992. Seasonal and sex variation in the mixed function oxygenase system of digestive gland microsomes of the common mussel, Mytilus edulis (L.). Comp. Biochem. Physiol., C 101, 81-91.

Kotake, Y., Tanigawa, T., Tanigawa, M., Ueno, I., Allen, D.R., Lai, C., 1996. Continuous monitoring of cellular nitric oxide generation by spin trapping with an iron-dithiocarbamate complex. Biochim. Biophys. Acta 1289, $362-368$.

Lawrence, R.A, Burk, R.F., 1976. Glutathione peroxidase activity in seleniumdeficient rat liver. Biochem. Biophys. Res. Commun. 71, 952-958.
Lesser, M.P., Kruse, V.A., 2004. Seasonal temperature compensation in the horse mussel, Modiolus modiolus: metabolic enzymes, oxidative stress and heat shock proteins. Comp. Biochem. Physiol., A 137, 495-504.

Livingstone, D.R., 1991. Organic xenobiotic metabolism in marine invertebrates. Adv. Comp. Environ. Physiol. 7, 45-185.

Malanga, G., Estevez, M.S., Calvo, J., Puntarulo, S., 2004. Oxidative stress in limpets exposed to different environmental conditions in the Beagle Channel. Aquat. Toxicol. 69, 299-309.

Marsh, A.G., Gremare, A., Dawson, R., Tenore, K.R., 1990. Translocation of algal pigments to oocytes in Capitella spec, I (Annelida: Polychaeta). Mar. Ecol., Prog. Ser. 67, 301-304.

Martell, A.E., 1982. Chelates of ascorbic acid formation and catalytic properties. In: Sieb, P.A., Tolbert, B.M (Eds.), Ascorbic Acid: Chemistry Metabolism and Uses. American Chemical Society, Washington, DC, pp. 153-178.

Miranda, K.M., Espey, M.G., Wink, D.A., 2001. A rapid, simple spectrophotometric method for simultaneous detection of nitrate and nitrite. Nitric Oxide: Biol. Chem. 5, 62-71.

Misra, H.P., Fridovich, I., 1972. The role of superoxide anion in the autoxidation of epinephrine and simple assay for superoxide dismutase. J. Biol. Chem. 247, 3170-3175.

Morriconi, E., Calvo, J., 1993. Influencia ambiental en el crecimiento alométrico de la valva de Nacella $(P$.) deaurata (Gmelin 1971) en el Canal Beagle. Malacologia 35, 1-6.

Morriconi, E., 1999. Reproductive biology of limpet Nacella (P.) deaurata (Gmelin 1971) in Bahía Lapataia (Beagle Channel). Sci. Mar. 63, 417-426.

Morricone, E., 2005. Tesis Doctoral: Ecología reproductiva de moluscos gastrópodos del canal de Beagle, Universidad Nacional de La Plata.

Peck, L.S., Veal, R., 2001. Feeding, metabolism and growth in the Antarctic limpet Nacella concinna (Strebel 1908). Mar. Biol. 138, 553-560.

Ramos-Vasconcelos, G.R., Cardoso, L.A., Hermes-Lima, M., 2005. Seasonal modulation of free radical metabolism in estivating land snails Helix aspersa. Comp. Biochem. Physiol., C 140, 165-174.

Roginsky, V.A., Stegmann, H.B., 1994. Ascorbyl radical as natural indicator of oxidative stress: quantitative regularities. Free Radic. Biol. Med. 17, 93-103.

Schöttler, U., 1989. Anaerobic metabolism in the lugworm Arenicola marina during low tide: the influence of developing reproductive cells. Comp. Biochem. Physiol., A 92, 1-7.

Sedlak, J., Lindsay, R.H., 1968. Estimation of total, protein bound, and nonprotein sulfhydryl groups in tissue with Ellman's reagent. Anal. Biochem. 25, 192-205.

Solé, M., Porte, C., Albaiges, J., 1995. Seasonal variation in the mixed function oxygenase system and antioxidant defenses of the mussel Mytilus galloprovincialis. Environ. Toxicol. Chem. 14, 157-164.

Viarengo, A., Canesi, L., Livingstone, D.R., 1991. Seasonal variations in the antioxidant defence enzymes and lipid peroxidation of the digestive gland of mussels. Comp. Biochem. Physiol., C 100, 187-190.

Wilhelm Filho, D., Torres, M.A., Tribess, T.B., Pedrosa, R.C., Soares, C.H.L., 2001a. Influence of season and pollution on the antioxidant defenses of the cichlid fish acará (Geophagus brasiliensis). Braz. J. Med. Biol. Res. 34, 719-726.

Wilhelm Filho, D., Tribess, T.B., Gáspari, C., Claudio, F.D., Torres, M.A., Magalhaes, A.R.M., 2001b. Seasonal changes in antioxidant defenses of the digestive gland of the brown mussel (Perna perna). Aquaculture 203, $149-158$. 